\title{
Biomedical research, a tool to address the health issues that affect African populations
}

\author{
Emmanuel Peprah ${ }^{1 *}$ and Ambroise Wonkam²
}

\begin{abstract}
Traditionally, biomedical research endeavors in low to middle resources countries have focused on communicable diseases. However, data collected over the past 20 years by the World Health Organization (WHO) show a significant increase in the number of people suffering from non-communicable diseases (e.g. heart disease, diabetes, cancer and pulmonary diseases). Within the coming years, WHO predicts significant decreases in communicable diseases while non-communicable diseases are expected to double in low and middle income countries in sub-Saharan Africa. The predicted increase in the non-communicable diseases population could be economically burdensome for the basic healthcare infrastructure of countries that lack resources to address this emerging disease burden. Biomedical research could stimulate development of healthcare and biomedical infrastructure. If this development is sustainable, it provides an opportunity to alleviate the burden of both communicable and non-communicable diseases through diagnosis, prevention and treatment. In this paper, we discuss how research using biomedical technology, especially genomics, has produced data that enhances the understanding and treatment of both communicable and non-communicable diseases in sub-Saharan Africa. We further discuss how scientific development can provide opportunities to pursue research areas responsive to the African populations. We limit our discussion to biomedical research in the areas of genomics due to its substantial impact on the scientific community in recent years however, we also recognize that targeted investments in other scientific disciplines could also foster further development in African countries.
\end{abstract}

Keywords: Genomics, Biomedical, Research, Africa, Development, Policy

\section{Background}

Advances in medicine using recent biomedical technologies, novel chemotherapeutic interventions and treatment regimens has allowed for rapid diagnosis and treatment of diseases, thus prolonging life for a significant number of people [1,2]. This is demonstrated by the substantial increase in the global life expectancy at birth in the past 20 years. Globally, male and female life expectancy has increased from 56.4 yrs and 61.2 yrs respectively to $67.5 \mathrm{yrs}$ and $73.3 \mathrm{yrs}$ in the decade from 1990 to 2010 [3]. In sub-Saharan Africa (SSA), substantial reductions in childhood mortality, through the introduction of life saving antiretroviral therapy and other preventative measures against communicable diseases are credited with the observed increases in life expectancy

\footnotetext{
* Correspondence: peprahek@mail.nih.gov

'Current address: National Institutes of Health, Building 1, RM 256A, Bethesda MD 20892, USA

Full list of author information is available at the end of the article
}

[3]. Whereas global life expectancy is the standard metric to measure the progress of countries toward combating disease resulting in prolonged life, another statistic, the healthy life expectancy (HALE) summarizes mortality and non-fatal outcomes of disease (e.g. longevity) in a single measure of averaged population health [4].

In 1990, countries with the lowest HALE for both sexes were in SSA except for Afghanistan [4]. Similar to life expectancy, HALE for a person at age 50 improved in the past 20 years (i.e. 1990 to 2010) for most countries, including many in SSA [4]. As increases in life expectancy occurred, years lived with disability (YLD) remained largely unchanged over the same 20-year period [5]. Life expectancy, HALE and YLD demonstrate that success has been mixed because: 1) as life expectancy has increased globally, countries in SSA are at the bottom of this and other measures and 2) the majority of diseases which have caused YLDs to remain relatively unchanged are non-communicable diseases (NCDs) and

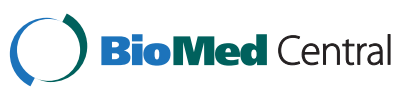


some communicable diseases (e.g. antiretroviral therapy for individuals have improved and increased the lifespan of many living with HIV/AIDS) [5].

With the observed increase in life expectancy, one could properly ask: Have genomic technologies contributed to this increase globally? If biomedical technologies, especially genomics have contributed to the increase in global life expectancy this would be one major justification for increased investment of these technologies in SSA. Although communicable diseases have decreased in SSA, the major challenges for the next few decades will include health issues associated with NCDs. Significant increases in YLDs for people living in SSA with well managed chronic conditions due to NCDs and infectious diseases will also become a challenge [5]. Biomedical science can play a role in combating the rise in NCDs and chronic conditions. For instance, biomedical science has the potential to improve the quality of life for many by identifying the optimal treatment regimens for several conditions [6-8]. Furthermore, the application of biomedical research to solve vexing problems has led to the creation of new fields of scientific inquiry and expansion of other areas spurring innovation $[9,10]$. In fact, publication of the human genome sequence has revolutionized medicine allowing the characterization of novel disease-related genetic variants. In this capacity, genomics (i.e. elucidating disease states by using technologies that characterize human and also non-human genomes) can be a very useful tool to further address communicable and non-communicable diseases in SSA because investments in biotechnology, especially genomics, have significantly impacted other regions. Although investments in genomic technologies have increased in other regions of the world, scientists in low- to middle-income countries that could utilize these technologies to improve health and to promote equity are concerned that the commercial development of genomic technologies will widen the gap between the developed and the developing world [11]. This concern was recognized by the World Health Organization (WHO) over a decade ago; the WHO commissioned the report Genomics and World Health in recognition of the potential and significant positive and negative impacts genomics could have on global health [12]. A decade after the WHO report was published, large-scale investments in biotechnology and human genomic studies have been made by Mexico, India, China and Thailand producing both economic and scientific dividends which we suggest have had a beneficial effect on life expectancy [2,13-15]. Within these countries an increase in life expectancy has been observed which can be attributed to medical innovation sparked by biotechnology and genomics (large scale vaccination programs), non-medical programs (continued education, improved literacy rate of the population) and other factors [16]. The factors necessary for the development and sustained utilization of large scale biotechnology including genomics, to develop sustainable economies are thoroughly discussed by Singer, Daar and colleagues $[2,13,17,18]$. This paper will express similar themes and focus on how biomedical research can address communicable and non-communicable diseases in Africa.

\section{Communicable diseases}

Globally, deaths from communicable diseases, and maternal, neonatal and nutritional causes decreased by $\sim 2.7$ million from 1990 to 2010 (from 15.9 million deaths to 13.2 million deaths respectively) [19]. Notwithstanding, this observed decrease in deaths from communicable diseases, Southeast Asia and Africa together bore 54\% of the total global burden of disease while accounting for only $40 \%$ of the world's population [20]. With the significant decrease in deaths from communicable diseases, SSA still accounts for a significant burden of communicable disease worldwide [20]. Interestingly, the decrease in deaths from communicable, maternal, neonatal, and nutritional causes was due to significant reductions in several diseases (i.e. diarrheal diseases, lower respiratory infections, neonatal disorders, measles and tetanus) which reflect scaling up of effective treatments and utilization of technologies to combat these disorders associated with poverty [19]. Other communicable diseases including HIV/AIDS and malaria, contributed to a massive increase in deaths from 1990 to 2010; however, this increase did not affect the overall decrease observed from aggressive scaling up of medical interventions for children (0-12 yrs), which were the major age group that died from communicable diseases [19]. The significant reduction in child deaths associated with communicable diseases has increased universal life expectancy.

Biomedical and genomic technologies have been used to derive host-parasite relationships (e.g. between humanparasite, parasite-vector, and human-vector interactions) that have significantly increased our understanding of these complex interactions [21,22]. Traditionally, fieldwork has occurred in SSA to sample zoonotic vectors, parasites and infected humans in the areas where outbreaks have occurred. Fieldwork has allowed sample collection resulting in the genomes of Plasmodium falciparum [23], Trypansoma brucei [24], Leishmania major [25], and Schistosoma mansoni [26] being sequenced with additional molecular, biochemical and bioinformatics analyses [27]. For instance, data acquired from those scientific endeavors have been used to develop new therapies for schistosomiasis [28], trypanosomiasis [29] and malaria [30], using both genomics and traditional approaches, which have decreased the burden of disease in SSA. Currently, researchers are testing combinations of malaria treatments to find regimens suitable for children and also 
to identify the development of drug resistance in malaria [6]. Another technology, the genome-wide associations study (GWAS), has been used to provide genetic candidates for the development of control measures against malaria [6,31]. Samples collected during outbreaks have yielded new discoveries about both the infectious agents and population susceptibilities. Moreover, systematic analysis of samples collected during outbreaks (e.g. large vector and parasite collections) has allowed for determination of parasite susceptibility using pharmacological compounds [32]. In the future, investigation of genetic diversity of both vector and parasites within the environment using genomics will shed light on the distribution, epidemiological importance and evolutionary history of malaria vectors in the African rainforest [33]. Many of these new efforts, in which genomic technologies were utilized to investigate malaria and other infectious diseases, are being led by African investigators in Africa and they include chemotherapeutic interventions [6,33-35]. Publications highlight the emerging evidence that African scientists, with support from local and international partners, are starting to set a research agenda for the continent. The aforementioned examples showcased in various publications include: 1) improved diagnosis, 2) scaling up of treatment, 3) elucidation of the development of drug resistance in unicellular organisms, 4) elucidation of human genetic variants that affect drug metabolism, and 5) development of genomic tools for population-level analysis of parasite and human $[14,36]$. In the field of infectious disease, application of genomics technologies has been instrumental in the elucidation of the complex biology of infectious agents and how they interact with hosts [37].

In addition to malaria, African scientists have used genomic technologies (such as GWAS) to characterize HIV/AIDS in SSA, which has gained significant attention from researchers inside and outside SSA $[7,38]$.
Genomic analysis of both African and non-African populations have found that several genetic variants (e.g. chemokine receptors, HLA, mannose-binding receptor and other genes) can provide increased resistance or susceptibility to HIV infections (Table 1) [7]. Africa could offer more research opportunities on HIV explicating the roles of these variants in HIV infections to improve prevention, care, and treatment prospects for individuals at risk of the disease [39]. Table 1 provides examples of GWAS and other studies pertaining to HIV, malaria, and tuberculosis which used mostly African and African ancestry populations (e.g. African Americans in the United States). Population-based genomic analyses has produced data about genetic susceptibility to disease and illuminated population-specific preventive approaches that could decrease HIV infections. Similar to the emergence of African investigators in the field of parasitology, many investigators on the African continent continue to elucidate HIV biology, treatment, transmission and also the effects of HIV on culture, social stigma and other negative societal issues of the disease [40-42].

We highlight genomics- and biotechnology-related research that was used to characterize and comprehend communicable diseases and demonstrate that this research has also led the way for substantial advances and improvements in the health of populations in SSA. Many countries (e.g. India, Brazil and China) have addressed communicable diseases by developing robust biotechnology industries [47,48]. Development of biotechnology (e.g. genomic research, and biopharmaceuticals) allows countries to benefit economically by lowering the cost of health-related products for local populations [48]. Globally, development of biotechnology has been a factor in increasing health and life expectancy in SSA, so we argue that a substantial investment in this area will produce significant benefit for SSA. We suggest that a similar model focused

Table 1 GWAS of African and African ancestry populations on communicable diseases obtained from the National Human Genome Research Institute catalogue of published genome-wide association studies (GWAS)

\begin{tabular}{|c|c|c|c|c|}
\hline Disease & Sample size & Replication sample size & Genes & Ref \\
\hline HIV (mother-to-child transmission) & $\begin{array}{l}100 \text { Malawian infant cases, } \\
126 \text { Malawian infant controls }\end{array}$ & NR & NS & {$[43]$} \\
\hline HIV-1 susceptibility & $\begin{array}{l}848 \text { Malawian cases, } \\
531 \text { Malawian controls }\end{array}$ & NR & $\begin{array}{l}\text { AL591509.5, GLRX3, TXNL3, FAM174B, } \\
\text { AC009271.7, ZDHHC19, BUD13 }\end{array}$ & [44] \\
\hline HIV-1 viral setpoint & $\begin{array}{l}496 \text { HIV-1 infected individuals } \\
\text { of African ancestry; } 302 \mathrm{HIV}-1 \\
\text { exposed and uninfected } \\
\text { individuals of African ancestry }\end{array}$ & NR & $\begin{array}{l}\text { VEGFC, EPHA5, HIST1H4A, AL391500.13, } \\
\text { KB-67B5.12, CMTM8, AC095058.3, } \\
\text { AC087190.5-2, DNAJC5B, ZFP90, MAD2L1, } \\
\text { HSP9OAB3P, Intergenic chr 2, GALNT14 }\end{array}$ & [45] \\
\hline Malaria & $\begin{array}{l}958 \text { Gambian cases; } 1,382 \\
\text { Gambian controls; all children }\end{array}$ & $\begin{array}{l}\text { 1,087 Gambian cases; 2,376 Gambian } \\
\text { controls, all children }\end{array}$ & $H B B, S C O 1, D D C$ & [31] \\
\hline Tuberculosis & $\begin{array}{l}921 \text { Ghanaian cases; } 1,740 \\
\text { Ghanaian controls, } 1,316 \\
\text { Gambian cases; } 1,382 \\
\text { Gambian controls }\end{array}$ & $\begin{array}{l}\text { 1,226 Ghanaian cases; } 3,825 \text { Ghanaian } \\
\text { controls; } 236 \text { Malawian cases; } 779 \\
\text { Malawian controls; } 332 \text { Ghana } \\
\text { parent/child trios and duos }\end{array}$ & GATA6,CTAGE1,RBBP8,CABLES1 & [46] \\
\hline
\end{tabular}


on chronic conditions could substantially mitigate the increases in NCDs as reported by the Global Burden of Disease 2010 report $[37,49,50]$.

\section{Non-communicable diseases}

Communicable diseases account for the plurality of deaths in many African countries; however, there is a need to increase biomedical research in the areas of NCD. The burden of NCDs (e.g. heart disease, diabetes, some cancers and pulmonary disease) are expected to double in lowand middle-income countries within the next few decades [51]. The number of deaths from NCDs rose in 2010 by almost 34.5 million globally as deaths caused by communicable diseases decreased [19]. It is predicted that the healthcare systems of these countries will not be able to support the treatment of NCDs (e.g. Sickle Cell Disease (SCD)) especially in African countries in which the health infrastructure is taxed by infectious diseases [51]. The increase in chronic diseases would suggests that a realignment of priorities is needed in which substantially greater focus should be on mitigating the projected increases in NCDs in SSA. We argue that genomic technologies can benefit African populations in the area of non-communicable diseases by briefly discussing the knowledge scientists have gained about NCDs using these technologies.

GWAS and other genomic technologies have had considerable influence on the identification of genetic variants associated with NCDs. Several GWAS on NCDs have been conducted with African and African ancestry populations. Asthma is a complex NCD that significantly affects both the young and old [52]. In the countries in which asthma has be explored, many have reported that hospitalizations for asthma are 2-3 times higher for African and African ancestry populations compared to other ethnic groups [52,53]. GWAS exploring the genetic basis of disease in African ancestry populations have identified several genes associated with asthma susceptibility (Table 2). GWAS have found that different genetics variants were associated with asthma susceptibility in children of European and African ancestry suggesting different biological mechanisms could be at the basis of asthma susceptibility in these diverse populations $[54,55]$.

Unlike asthma, the primary genetic variant underlying SCD has been identified, but the tools of GWAS are being used to determine the nature of the genetic modifiers associated with phenotypic diversity in SCD. SCD is the most common monogenic disease, occurring at its highest frequency in SSA [61]. As an illustration, people suffering from SCD will increasing effect public healthcare systems in SSA; it is predicted that 312,000 neonates with SCD are born globally with $\sim 240,000$ of those births being in SSA [62]. The combined populations of births of heterozygous and homozygous carriers of the SCD gene mutation HbAS is estimated at $~ 3.6$ million and for HbSS $\sim 240,000$, respectively, producing an estimated $\sim 4$ million live births per year with SCD gene mutation [62]. In this capacity, SCD and other hemoglobinopathies represent a health

Table 2 GWAS on non-communicable diseases in African and recent African ancestry populations obtained from the National Human Genome Research Institute catalogue of published genome-wide association studies (GWAS)

\begin{tabular}{|c|c|c|c|c|}
\hline Disease/Trait & Sample size & Replication sample size & Genes & Ref \\
\hline Asthma & 422 cases; 1,533 controls & $\begin{array}{l}\text { 3,750 white cases; } 13,365 \text { white controls; } \\
592 \text { white trios; } 1,903 \text { black cases; } 2,432 \\
\text { black controls; } 929 \text { black family members }\end{array}$ & PDE4D & {$[55]$} \\
\hline Asthma & $\begin{array}{l}464 \text { African American cases; } 471 \\
\text { African American controls; 1,028 } \\
\text { African Caribbean family members }\end{array}$ & $\begin{array}{l}994 \text { European descent cases; 1,243 } \\
\text { European descent controls; 2,331 African } \\
\text { descent cases, 2,874 African descent } \\
\text { controls (includes family members) }\end{array}$ & NS & {$[56]$} \\
\hline Asthma & $\begin{array}{l}793 \text { European ancestry child cases; } \\
1,988 \text { European ancestry child controls }\end{array}$ & $\begin{array}{l}917 \text { European ancestry child cases; } \\
\text { 1,546 European ancestry child controls; } \\
\text { 1,667 African American child cases; } \\
\text { 2,045 African American child controls }\end{array}$ & DENND1B, CRB1 & {$[54]$} \\
\hline Asthma & $\begin{array}{l}\text { 2,088 European American cases; } \\
\text { 1,612 African American and African } \\
\text { Caribbean cases; 1,688 Latino cases }\end{array}$ & $\begin{array}{l}\text { 2,727 European American cases; 2,147 } \\
\text { African American and African Caribbean } \\
\text { case; 2,299 Latino cases }\end{array}$ & $\begin{array}{l}\text { GSDMB, IL1RL1, TSLP, IL33, } \\
\text { PYHIN1, C11orf71, CRCT1 }\end{array}$ & {$[57]$} \\
\hline Sickle cell anemia (severity) & $\begin{array}{l}177 \text { African American severe patients; } \\
\text { 1,088 African American mild patients }\end{array}$ & 68 severe patients; 95 mild patients & NS & {$[58]$} \\
\hline Sickle cell anemia (HbF modifiers) & $\begin{array}{l}2040 \text { African American sickle cell } \\
\text { anemia patients }\end{array}$ & NR & $B C L 11 A, H B S 1 L-M Y B$ & {$[59]$} \\
\hline Podoconiosis & 194 cases and 203 controls from Africa & $\begin{array}{l}202 \text { family trios (two parents and one } \\
\text { affected child) for family-based association } \\
\text { testing; } 94 \text { cases and } 94 \text { controls for } \\
\text { HLA-typing }\end{array}$ & HLA-DQA1 & {$[60]$} \\
\hline
\end{tabular}


burden comparative to that of communicable diseases in SSA [63]. An example of effective application of genomic technology for SCD in SSA could be the wide scale early diagnosis and preventive treatment of SCD, along with other hemoglobinopathies and monogenic disorders. The burden of SCD is disproportionately located in Africa; thus, prioritizing diagnosis, treatment and prevention for the low- and middle-income countries would be an effective means of bridging the gap between these and highincome countries. Furthermore, introduction of preventive genetic methods such as the utilization of DNA technology in childhood disease screenings to identify causal genetic variants would be beneficial to populations in SSA and considered an appropriate point of entry for genomic technologies [11]. An example that occurred in SSA is a Cameroonian center that recently introduced detection for SCD; this service offers reproductive options to families [64].

Moreover, genes implicated in SCD severity have been shown to modulate fetal hemoglobin (HbF) levels and were confirmed by GWAS in African and African ancestry populations [65]. A study showed that the 3 loci described in other populations that affect HbF levels and clinical severity has a significant impact in Tanzanian patients [66]; however, some variants affecting $\mathrm{HbF}$ in Tanzanians are not well represented in European populations. This and other similar findings suggest that there is a need to search for additional loci through independent GWAS in African populations [66]. Identifying loci that affect $\mathrm{HbF}$ levels and, consequently, disease severity could be used to anticipate one's ability to produce $\mathrm{HbF}$ from birth, and plan in advance the introduction of treatment (e.g. hydroxyurea, a drug which has been shown to increase concentrations of $\mathrm{HbF}$ ) to reduce the negative impact of SCD, which could include pain crises, acute chest syndrome and severe anemia resulting in blood transfusions [67]. Interestingly, evidence supports asthma and SCD as distinct co-morbid conditions in which the underlying mechanisms of phenotypic variations of the two diseases might be similar [68-70]. Table 2 lists GWAS studies that have found associations for genetic variants in NCDs. For both asthma and SCD, the complexity of the phenotype would suggest that genetic heterogeneity is a major contributor to the clinical severity in both diseases. Furthermore, the diversity within African populations can lead to a comprehensive characterization of genetic variants associated these both asthma and SCD.

Another NCD, Podoconiosis also called non-filarila elephantiasis of the lower leg, occurs in SSA because of environmental exposure to soil. Recently, family-based association study using GWAS was conducted to elucidate the genetic underpinnings of podoconiosis. This study, focused on continental African population groups, found genetic susceptibility to podoconiosis [60]. In addition to identifying genes associated with NCDs such as podoconisosis, GWAS has been used to identify treatment outcomes based on genotypes for NCDs. Overall; genomicsrelated biomedical research has given a better picture of the genetic underpinnings and molecular biology of many of these diseases which affect SSA populations.

The Global Burden of Disease 2010 reported substantial increases in cardiovascular disease; ischaemic heart disease, stroke and chronic obstructive pulmonary disease were among the leading causes of death globally [19]. In SSA, many have recognized that cardiovascular diseases are a significant contributor to mortality; for example, in Kenya, acute myocardial infarctions are not uncommon [71]. Tanzania has observed a significant increase in the number of deaths for cardiovascular disease (from 16\% in 2003 to $24 \%$ in 2007) [72]. In hypertension, genetic variants found in African ancestry populations are associated with differential responses to antihypertensive drugs (e.g. thiazide diuretics) commonly used to regulate blood pressure [73]. These genetic variants offer ways to distinguish good responders (patients that show improvement on diuretics) from non- or poor-responders (patients with a negative response to diuretic mediations for the treatment of hypertension) which provide information on how best to treat hypertensive patients. Because of this escalating dilemma faced by low- to middle-income countries in SSA, considerable resources will be needed to address the observed and impending ballooning of NCDs (e.g. hypertension and cardiovascular diseases) in the coming decades $[19,72]$.

The observed increases of NCDs for the past 20 years (1990 to 2010) are due to factors that include demographic changes leading to a rise in the proportion of people older than 60 years $[4,19]$. This continued increase in life expectancy has not been homogeneous globally among age groups [3]. The heterogeneous distribution of life expectancy globally has resulted in an increase in people living longer with chronic conditions in SSA [74]. The scale of the challenge posed by the combined and growing burden of chronic infectious diseases and NCDs, including genetic conditions, demands an extraordinary response that few SSA countries currently provide. With the increase in life expectancy due to positive treatment outcomes and increased prevention of disease, SSA will increase its populations of the chronically ill in the coming decades. This situation is illustrated by WHO data indicating that life expectancy has risen; however, YLDs has remained constant globally [5]. We suggest that biotechnology and genomics can be used to address many of the issues associated with NCDs, similar to their use in infectious disease research. Also, a gradual increase in resources available to understand NCDs, while also addressing communicable diseases, is needed [75]. Essentially, we envision a model in which, as the burden of infectious diseases 
decreases, would create an opportunity to increase research focused on NCDs.

\section{Challenges for genomics research in Africa}

The present state of genomic research in Africa is in its infancy; nevertheless, substantial biomedical research continues to occur in the areas of agriculture, genetics, biomedical science and several other areas [17]. Excluding South Africa, research funding amounts to $<.5 \%$ of GPD indicating that the majority of funding for scientific research, training and infrastructural development occur through support from high-income countries [76]. Many have suggested that the influx of donor money to support African research has had a negative impact in which relatively wealthy nations (e.g. Nigeria and Angola) do not invest in funding to support biomedical research [77-79]. However, it must be acknowledged that significant infrastructure exists in Africa for biomedical research. The challenges that exist for genomics research in Africa include improving infrastructure, and creating and maintaining sustainable collaborations that are currently present on the continent.

Infrastructure for various research centers has been created with financial and technical investment from the United Nations, world governments, and biotechnology companies with business interests on the continent $[13,80]$. Currently infrastructure exists in South Africa, Egypt, Tunisia, Nigeria and Kenya [81]. These centers have also made substantial investments in agricultural science compared to other Africa countries and are increasing their research capacity [81]. Recently, African countries have started to realize the necessity of developing a vibrant research infrastructure from local government investments [51]. To address the issue of local investment, members of the African Union (AU) of countries have agreed to steadily increase funding for research until it reaches at least 1\% of GDP within the next few years [76]. This is a significant development and it demonstrates that AU partner nations understand the value of research as a potential mechanism to: 1 ) decrease the burden of disease that affects their populations, 2) create cheaper and "home grown" alternatives to pharmacological agents that are usually purchased from high-income countries, 3) acknowledge the economic benefits that investments in research infrastructure can develop through home-grown companies, which in turn provide jobs to citizens who eventually pay taxes [2]. Local investments have occurred in many countries in the Southern Hemisphere allowing these countries to improve their economies which could be suggested as a way forward for SSA $[2,15,18]$.

A second challenge for genomics research in Africa concerns research priorities of African countries and the high-income countries which fund and support research. Research priorities between high-income countries (i.e. United Kingdom, USA) and low- to middle-income African countries differ in many areas [81]. In addition to the differences, because SSA countries have a significant communicable disease burden, and disproportionately have more individuals affected by YLDs, African led research endeavors could significantly reduce the mortality associated with those diseases $[5,76,79]$. The differences in research priorities between African countries and highincome countries is illustrated by the lack of attention to diarrhoeal diseases (DD) and lower respiratory infections (LRI), which cause significant mortality in children in SSA [5]. In 2006, only 26 clinical trials occurred for DD and LRI (20 for DD and 6 for LRI) compared to 205 for malaria [81]. This suggests the need for further development of resources for African scientists to develop their own research priorities. Case studies in Cameroon and Tanzania illustrate the potential of genomic research in SCD and its applications in public health interventions. More studies to characterize genomic variations that affect phenotypes of SCD and their application in primary and secondary preventions, as well as prospective studies on genomic-based therapeutic interventions, could allow Africa, where twothirds of SCD patients live, play a major global role in hemoglobinopathies research. With a significant decrease in communicable diseases observed in the past 20 years for SSA, a monumental shift has begun, suggesting a realignment of goals and priorities for the next few decades $[4,5,19]$. This realignment of priorities will occur as SSA considers how best to address the ageing population.

The third challenge is overcoming the scientific diasporas that have emerged between low- to middle-income countries compared to high-income countries $[50,82]$. The large migration of physicians, nurses, scientists and other highly educated professionals to high-income countries termed, "brain drain", is of considerable significance to economic development [82]. African countries are placed in a disadvantaged position for technology development because professional, highly educated cadres of people are needed to develop, operate and maintain these technologies and lead scientific endeavors. This migration was illustrated in a 2004 report which stated that the import of highly qualified medical professionals from Ghana saved $\sim £ 103$ million ( $\sim 200$ million) in training costs for the National Health Service in the United Kingdom [83]. From this observation, some have argued compensation for the country of origin was needed to offset the loss of this important and critical human capital [84]. Currently, in many regions of Africa with stable economies, migration is due to low salary for professionals [49]. The migration problem is prevalent in medicine and other scientific fields [85]. Several groups have suggested that brain drain is one major cause of scientific diasporas between industrialized and emerging nations [50]. Other groups suggest that the lack of infrastructure, economic development and 
governance are issues that must be addressed and brain drain is a symptom of these problems [18]. To address how these problems have arisen, it is important to examine the scientific diasporas in a new paradigm in which engagement of the continent, with equal partnership in developing collaborative research priorities which are also associated with economic development is paramount [86].

This scientific diasporas can be overcome via several mechanisms [50]. Even-though these mechanisms do not replace the loss in human capital, the mechanisms can mitigate losses through: 1) support of local foreign scientists, 2) establishment of equal partnerships in collaborative efforts between foreign-born scientists residing in industrialized countries with leaders and scientists of their countries of origins, 3) specific targeted compensation to build genomics/biomedical/health infrastructure, and 4) technology transfer among public and private sectors, which have been shown to be successful in many countries [86]. Within this framework, a balance will be needed for providing incentives for individuals to return to their country of origin versus training scientists and developing infrastructure. We must also acknowledge that corruptions and/or mismanagement of these well-intentioned programs can perturb any advances; however, a multifaceted approach would be important to overcome the barriers expressed in the first challenge. We advocate a multitiered approach because it has been shown to have success in South and Central America and in Asia [13,15]. The multitiered approach allows for investment in several areas while also balancing competing interests. The situation in SSA is quite challenging; nonetheless, if the recommendations are implemented within SSA success is also possible $[13,18,87]$.

Overall a positive perception of research conducted by African scientists in SSA is gaining momentum, but it will take several years for this new paradigm to be the norm by which research occurs in Africa. The aforementioned challenges are not exhaustive but are significant barriers to development of biomedical technologies. A significant need to establish and implement ethical guidelines that allow international researchers conducting research in Africa to create capacity and also to help train the next generation of African scientists should be addressed. These issues are not only for the international community but also for African scientists who have significant obligations to develop the research infrastructure and culture within their own countries. For example, several areas that could be addressed without significant international coordination include collaboration amongst African scientists in Africa. African scientists could increase collaborations in areas of training, education and research which in turn will increase synergies in biomedical and genomic research producing a lower cost for everyone involved. These among other factors present unique opportunities for developing biomedical research emphasizing genomics within Africa.

\section{Conclusion}

The challenges and potential to address the health issues of African populations are not unique to SSA because many countries (e.g. India, Mexico, Brazil and China) have used the development of biomedical research technologies including genomics to begin addressing the health issues of their respective populations [2,13]. In SSA, the Republic of South Africa has embraced many of the tenants of globalization including supporting the developing biotechnology sector [87]. In theory using biomedical research to develop scientific capacity in Africa could significantly reduce the migration of intellect from low- to high-income countries. Development of biomedical research including genomics research in Africa could provide networking opportunities for African research scientists, clinicians, social scientists and bioethicists. Similarly, networking by African scientists from different fields was instrumental in the foundation of several research consortia (e.g. MalariaGEN, and HapMap). This collaborative spirit has also sponsored African students (potential research leaders) and African scientists from the Diaspora to attend annual meetings in Africa [88,89]. Such African Diaspora participation generates collaborations with local African scientists working in Africa that could ultimately mitigate brain drain by fostering interaction [90]. The issue of brain drain cannot be solved without budgetary commitment from SSA countries which stand to significantly benefit from the reduction in migration from SSA to high income countries.

With the budgetary constraints of many low- to middleincome African economies, committing funds to support biomedical- and genomics-related research might be viewed by some as an esoteric exercise. The immediate needs for medications to prevent infectious and noninfectious diseases in many regions of Africa are paramount but should not obscure the future health needs of the population. We argue that in addition to addressing the health needs of the population in the present, a vision for the future is also needed. This vision should include addressing the growing burden of NCDs while also recognizing the need to develop policies which promote economic development through science and biotechnology development. The needs of the populations in SSA can be addressed while contemporaneously building a future based on intellectual investment in people using models from other countries. The research needs for future populations start in the present in which biomedical research, including genomics could be indispensable. In terms of economics, biomedical research (such as genomics) offers ways to foster home grown development, manufacturing, and diagnosis and also inform on 
the delivery of healthcare. There is a tremendous opportunity for biomedical research to flourish in Africa based on examples by many South/South collaborations; furthermore, strong government commitment must be made for the promise of biomedical research to be delivered to the African continent.

\section{Competing interests}

The authors declare no competing interests.

\section{Acknowledgements}

The authors would like to thank Cindy Clark, NIH for her thorough comments in helping prepare this manuscript.

\section{Author details}

'Current address: National Institutes of Health, Building 1, RM 256A, Bethesda MD 20892, USA. ${ }^{2}$ Division of Human Genetics, Faculty of Health Sciences, University of Cape Town, Anzio Road-7925, Observatory, Cape Town, South Africa.

Received: 30 November 2012 Accepted: 5 August 2013

Published: 21 October 2013

\section{References}

1. McKillop AM, Flatt PR: Emerging applications of metabolomic and genomic profiling in diabetic clinical medicine. Diabetes Care 2011, 34:2624-2630

2. Hardy BJ, Seguin B, Goodsaid F, Jimenez-Sanchez G, Singer PA, Daar AS: The next steps for genomic medicine: challenges and opportunities for the developing world. Nat Rev Genet 2008, 9(Suppl 1):S23-S27.

3. Wang H, Dwyer-Lindgren L, Lofgren KT, Rajaratnam JK, Marcus JR, Levin-Rector A, Levitz CE, Lopez AD, Murray CJ: Age-specific and sex-specific mortality in 187 countries, 1970-2010: a systematic analysis for the Global Burden of Disease Study 2010. Lancet 2012, 380:2071-2094.

4. Salomon JA, Wang H, Freeman MK, Vos T, Flaxman AD, Lopez AD, Murray CJ: Healthy life expectancy for 187 countries, 1990-2010: a systematic analysis for the Global Burden Disease Study 2010. Lancet 2012, 380:2144-2162.

5. Vos T, Flaxman AD, Naghavi M, Lozano R, Michaud C, Ezzati M, Shibuya K, Salomon JA, Abdalla S, Aboyans V, et al: Years lived with disability (YLDs) for 1160 sequelae of 289 diseases and injuries 1990-2010: a systematic analysis for the Global Burden of Disease Study 2010. Lancet 2012, 380:2163-2196.

6. Charle P. Berzosa P, de Lucio A, Raso J, Nseng Nchama G, Benito A: Artesunate/Amodiaquine Malaria Treatment for Equatorial Guinea (Central Africa). Am J Trop Med Hyg 2013, 88:1087-1092.

7. Sirugo G, Hennig BJ, Adeyemo AA, Matimba A, Newport MJ, Ibrahim ME, Ryckman KK, Tacconelli A, Mariani-Costantini R, Novelli G, et al: Genetic studies of African populations: an overview on disease susceptibility and response to vaccines and therapeutics. Hum Genet 2008, 123:557-598.

8. Wilkin TJ, Gulick RM: CCR5 antagonism in HIV infection: current concepts and future opportunities. Annu Rev Med 2012, 63:81-93.

9. Di Berardino MA: Animal cloning-the route to new genomics in agriculture and medicine. Differentiation 2001, 68:67-83.

10. Burt DW: Chicken genome: current status and future opportunities. Genome Res 2005, 15:1692-1698.

11. Alwan A, Modell B: Recommendations for introducing genetics services in developing countries. Nat Rev Genet 2003, 4:61-68.

12. World Health Organization. Advisory Committee on Health Research: Genomics and world health : report of the Advisory Committee on Health Research. Geneva: World Health Organization; 2002.

13. Melon CC, Ray M, Chakkalackal S, Li M, Cooper JE, Chadder J, Ke W, Li L, Madkour MA, Aly S, et al: A survey of South-north health biotech collaboration. Nat Biotechnol 2009, 27:229-232.

14. Singer PA, Daar AS: Harnessing genomics and biotechnology to improve global health equity. Science 2001, 294:87-89.

15. Thorsteinsdottir H, Melon CC, Ray M, Chakkalackal S, Li M, Cooper JE, Chadder J, Saenz TW, Paula MC, Ke W, et al: South-South entrepreneurial collaboration in health biotech. Nat Biotechnol 2010, 28:407-416.

16. Lim SS, Vos T, Flaxman AD, Danaei G, Shibuya K, Adair-Rohani H, Amann M, Anderson HR, Andrews KG, Aryee M, et al: A comparative risk assessment of burden of disease and injury attributable to 67 risk factors and risk factor clusters in 21 regions, 1990-2010: a systematic analysis for the Global Burden of Disease Study 2010. Lancet 2012, 380:2224-2260.

17. Ray M, Daar AS, Singer PA, Thorsteinsdottir H: Globetrotting firms: Canada's health biotechnology collaborations with developing countries. Nat Biotechnol 2009, 27:806-814.

18. Singer PA, Court EB, Bhatt A, Frew SE, Greenwood H, Persad DL, Salamanca-Buentello F, Seguin B, Taylor AD, Daer HT, Daar AS: Applying genomics-related technologies for Africa's health needs. Afr J Med Med Sci 2007, 36(Suppl):7-14.

19. Lozano R, Naghavi M, Foreman K, Lim S, Shibuya K, Aboyans V, Abraham J, Adair T, Aggarwal R, Ahn SY, et al: Global and regional mortality from 235 causes of death for 20 age groups in 1990 and 2010: a systematic analysis for the Global Burden of Disease Study 2010. Lancet 2012, 380:2095-2128.

20. The Global Burden of Disease: 2004 Update. http://www.who.int/ healthinfo/global_burden_disease/2004 report_update/.

21. Ekland EH, Fidock DA: Advances in understanding the genetic basis of antimalarial drug resistance. Curr Opin Microbiol 2007, 10:363-370.

22. Westenberger SJ, Cui L, Dharia N, Winzeler E: Genome-wide nucleosome mapping of Plasmodium falciparum reveals histone-rich coding and histone-poor intergenic regions and chromatin remodeling of core and subtelomeric genes. BMC Genomics 2009, 10:610.

23. Gardner MJ, Hall N, Fung E, White O, Berriman M, Hyman RW, Carlton JM, Pain A, Nelson KE, Bowman S, et al: Genome sequence of the human malaria parasite Plasmodium falciparum. Nature 2002, 419:498-511.

24. Berriman M, Ghedin E, Hertz-Fowler C, Blandin G, Renauld H, Bartholomeu DC, Lennard NJ, Caler E, Hamlin NE, Haas B, et al: The genome of the African trypanosome Trypanosoma brucei. Science 2005, 309:416-422.

25. Ivens AC, Peacock CS, Worthey EA, Murphy L, Aggarwal G, Berriman M, Sisk E, Rajandream MA, Adlem E, Aert R, et al: The genome of the kinetoplastid parasite, Leishmania major. Science 2005, 309:436-442.

26. Berriman M, Haas BJ, LoVerde PT, Wilson RA, Dillon GP, Cerqueira GC, Mashiyama ST, Al-Lazikani B, Andrade LF, Ashton PD, et al: The genome of the blood fluke Schistosoma mansoni. Nature 2009, 460:352-358.

27. Webster JP, Oliviera G, Rollinson D, Gower CM: Schistosome genomes: a wealth of information. Trends Parasitol 2010, 26:103-106.

28. Driguez P, Doolan DL, Loukas A, Felgner PL, McManus DP: Schistosomiasis vaccine discovery using immunomics. Parasit Vectors 2010, 3:4.

29. Magez S, Radwanska M: African trypanosomiasis and antibodies: implications for vaccination, therapy and diagnosis. Future Microbiol 2009, 4:1075-1087.

30. Kappe S, Vaughan A, Boddey J, Cowman A: That was then but this is now: malaria research in the time of an eradication agenda. Science 2010 , 328:862-866

31. Jallow M, Teo YY, Small KS, Rockett KA, Deloukas P, Clark TG, Kivinen K, Bojang KA, Conway DJ, Pinder M, et al: Genome-wide and fine-resolution association analysis of malaria in West Africa. Nat Genet 2009, 41:657-665.

32. Peacock $C$ : Host and parasite genomics, an Australasian perspective. Parasite Immunol 2010, 32:599-606.

33. Ndo C, Simard F, Kengne P, Awono-Ambene P, Morlais I, Sharakhov L Fontenille D, Antonio-Nkondjio C: Cryptic Genetic Diversity within the Anopheles nili group of Malaria Vectors in the Equatorial Forest Area of Cameroon (Central Africa). PLOS ONE 2013, 8:e58862.

34. Miiro GM, Ouwe Missi Oukem-Boyer O, Sarr O, Rahmani M, Ntoumi F, Dheda K, Pym A, Mboup S, Kaleebu P: EDCTP regional networks of excellence: initial merits for planned clinical trials in Africa. BMC Public Health 2013, 13:258.

35. Agu PU, Ogboi JS, Akpoigbe K, Okeke T, Ezugwu E: Impact of Plasmodium falciparum and hookworm infections on the frequency of anaemia in pregnant women of rural communities in Enugu, South East Nigeria. Pan Afr Med J 2013, 14:27.

36. Pang T, Weatherall D: Genomics and global health - Hype, reality, and a call for action in the developing and the developed world. BMJ 2002, 324:1051-1052.

37. Lustigman S, Geldhof P, Grant WN, Osei-Atweneboana MY, Sripa B, Basanez MG. A research agenda for helminth diseases of humans: basic research and enabling technologies to support control and elimination of helminthiases. PLoS Negl Trop Dis 2012, 6:e1445.

38. Warnich L, Drogemoller BI, Pepper MS, Dandara C, Wright GE: Pharmacogenomic Research in South Africa: Lessons Learned and 
Future Opportunities in the Rainbow Nation. Curr Pharmacogenomics Person Med 2011, 9:191-207.

39. Palermo RE, Fuller DH: Omics Investigations of HIV and SIV Pathogenesis and Innate Immunity. Curr Top Microbiol Immunol 2013, 363:87-116.

40. Cherutich P, Bunnell R, Mermin J: HIV Testing: Current Practice and Future Directions. Curr HIV/AIDS Rep 2013, 10:134-141.

41. Nglazi MD, Kaplan R, Caldwell J, Peton N, Lawn SD, Wood R, Bekker LG: Antiretroviral treatment uptake in patients with HIV-associated TB attending co-located TB and ART services. S Afr Med J 2012, 102:936-939.

42. Joska JA, Sorsdahl KR: Integrating Mental Health into General Health Care: Lessons From HIV. Afr J Psychiatry 2012, 15:420-423.

43. Joubert BR, Lange EM, Franceschini N, Mwapasa V, North KE, Meshnick SR: A whole genome association study of mother-to-child transmission of HIV in Malawi. Genome Med 2010, 2:17.

44. Petrovski S, Fellay J, Shianna KV, Carpenetti N, Kumwenda J, Kamanga G, Kamwendo DD, Letvin NL, McMichael AJ, Haynes BF, et al: Common human genetic variants and HIV-1 susceptibility: a genome-wide survey in a homogeneous African population. AIDS 2011, 25:513-518.

45. Lingappa JR, Petrovski S, Kahle E, Fellay J, Shianna K, McElrath MJ, Thomas KK, Baeten JM, Celum C, Wald A, et al: Genomewide association study for determinants of HIV-1 acquisition and viral set point in HIV-1 serodiscordant couples with quantified virus exposure. PLOS One 2011, 6:e28632.

46. Thye T, Vannberg FO, Wong SH, Owusu-Dabo E, Osei I, Gyapong J, Sirugo G, Sisay-Joof F, Enimil A, Chinbuah MA, et al: Genome-wide association analyses identifies a susceptibility locus for tuberculosis on chromosome 18q11.2. Nat Genet 2010, 42:739-741.

47. Rezaie R, McGahan AM, Daar AS, Singer PA: Innovative drugs and vaccines in China, India and Brazil. Nat Biotechnol 2012, 30:923-926.

48. Rezaie R, McGahan AM, Frew SE, Daar AS, Singer PA: Emergence of biopharmaceutical innovators in China, India, Brazil, and South Africa as global competitors and collaborators. Health Res Policy Syst 2012, 10:18.

49. McCoy D, Bennett S, Witter S, Pond B, Baker B, Gow J, Chand S, Ensor T, McPake B: Salaries and incomes of health workers in sub-Saharan Africa. Lancet 2008, 371:675-681.

50. Seguin B, Singer PA, Daar AS: Science community: scientific diasporas. Science 2006, 312:1602-1603.

51. Boutayeb A, Boutayeb S: The burden of non communicable diseases in developing countries. Int J Equity Health 2005, 4:2.

52. Redd SC: Asthma in the United States: burden and current theories. Environ Health Perspect 2002, 110(Suppl 4):557-560.

53. Lenoir M, McGill CL, Graham LM Jr, Foggs M, Robinson S, Crim C, Stempel DA: A new focus on assessing and treating asthma control in the African-American community: a call to action. J Natl Med Assoc 2008, 100:1-23.

54. Sleiman PM, Flory J, Imielinski M, Bradfield JP, Annaiah K, Willis-Owen SA, Wang K, Rafaels NM, Michel S, Bonnelykke K, et al: Variants of DENND1B associated with asthma in children. N Engl J Med 2010, 362:36-44.

55. Himes BE, Hunninghake GM, Baurley JW, Rafaels NM, Sleiman P, Strachan DP, Wilk JB, Willis-Owen SAG, Klanderman B, Lasky-Su J, et al: Genome-wide Association Analysis Identifies PDE4D as an Asthma-Susceptibility Gene. Am J Hum Genet 2009, 84:581-593.

56. Mathias RA, Grant AV, Rafaels N, Hand T, Gao L, Vergara C, Tsai YJ, Yang M, Campbell M, Foster $C$, et al: A genome-wide association study on African-ancestry populations for asthma. J Allergy Clin Immunol 2010, 125:336-346 e334.

57. Torgerson DG, Ampleford EJ, Chiu GY, Gauderman WJ, Gignoux CR, Graves PE, Himes BE, Levin AM, Mathias RA, Hancock DB, et al: Meta-analysis of genomewide association studies of asthma in ethnically diverse North American populations. Nature Genet 2011, 43:887-892.

58. Sebastiani P, Solovieff N, Hartley SW, Milton JN, Riva A, Dworkis DA, Melista E, Klings ES, Garrett ME, Telen MJ, et al: Genetic modifiers of the severity of sickle cell anemia identified through a genome-wide association study. Am J Hematol 2010, 85:29-35.

59. Bae HT, Baldwin CT, Sebastiani P, Telen MJ, Ashley-Koch A, Garrett M, Hooper WC, Bean CJ, Debaun MR, Arking DE, et al: Meta-analysis of 2040 sickle cell anemia patients: BCL11A and HBS1L-MYB are the major modifiers of HbF in African Americans. Blood 2012, 120:1961-1962.

60. Tekola Ayele F, Adeyemo A, Finan C, Hailu E, Sinnott P, Burlinson ND, Aseffa A, Rotimi CN, Newport MJ, Davey G: HLA Class II Locus and Susceptibility to Podoconiosis. N Engl J Med 2012, 366:1200-1208.
61. Aygun B, Odame I: A global perspective on sickle cell disease. Pediatr Blood Cancer 2012, 59:386-390.

62. Piel FB, Patil AP, Howes RE, Nyangiri OA, Gething PW, Dewi M, Temperley WH, Williams TN, Weatherall DJ, Hay Sl: Global epidemiology of sickle haemoglobin in neonates: a contemporary geostatistical model-based map and population estimates. Lancet 2013, 381:142-151.

63. Weatherall D: Hemoglobinopathies worldwide: present and future. Curr Mol Med 2008, 7:592-599.

64. Wonkam A, Tekendo CN, Sama DJ, Zambo H, Dahoun S, Bena F, Morris MA: Initiation of a medical genetics service in sub-Saharan Africa: experience of prenatal diagnosis in Cameroon. Eur J Med Genet 2011, 54:e399-e404.

65. Bhatnagar P, Purvis S, Barron-Casella E, DeBaun MR, Casella JF, Arking DE, Keefer JR: Genome-wide association study identifies genetic variants influencing F-cell levels in sickle-cell patients. J Hum Genet 2011, 56:316-323.

66. Makani J, Menzel S, Nkya S, Cox SE, Drasar E, Soka D, Komba AN, Mgaya J, Rooks H, Vasavda N, et al: Genetics of fetal hemoglobin in Tanzanian and British patients with sickle cell anemia. Blood 2011, 117:1390-1392.

67. Strouse JJ, Lanzkron S, Beach MC, Haywood C, Park H, Witkop C, Wilson RF, Bass EB, Segal JB: Hydroxyurea for sickle cell disease: a systematic review for efficacy and toxicity in children. Pediatrics 2008, 122:1332-1342

68. Field JJ, DeBaun MR: Asthma and sickle cell disease: two distinct diseases or part of the same process? Hematology Am Soc Hematol Educ Program 2009:45-53. doi:10.1182/asheducation-2009.1.45.

69. Morris CR: Asthma management: reinventing the wheel in sickle cell disease. Am J Hematol 2009, 84:234-241.

70. Caboot JB, Allen JL: Pulmonary complications of sickle cell disease in children. Curr Opin Pediatr 2008, 20:279-287.

71. Ogeng'o JA, Olabu BO, Ong'era D, Sinkeet SR: Pattern of acute myocardial infarction in an African country. Acta Cardiol 2010, 65:613-618.

72. Narh-Bana SA, Chirwa TF, Mwanyangala MA, Nathan R: Adult deaths and the future: a cause-specific analysis of adult deaths from a longitudinal study in rural Tanzania 2003-2007. Trop Med Int Health 2012, 17:1396-1404

73. Turner ST, Bailey KR, Fridley BL, Chapman AB, Schwartz GL, Chai HS, Sicotte H, Kocher JP, Rodin AS, Boerwinkle E: Genomic association analysis suggests chromosome 12 locus influencing antihypertensive response to thiazide diuretic. Hypertension 2008, 52:359-365.

74. Mayosi BM, Flisher AJ, Lalloo UG, Sitas F, Tollman SM, Bradshaw D: The burden of non-communicable diseases in South Africa. The Lancet 2009, 374:934-947.

75. Ramsay M: Africa: continent of genome contrasts with implications for biomedical research and health. FEBS Lett 2012, 586:2813-2819.

76. Nordling L: African nations vow to support science. Nature 2010, 465:994-995.

77. Bateman C: Corruption busting: a real health threat. S Afr Med J 2011, 101:360. 362.

78. Okafor UV: Challenges in critical care services in Sub-Saharan Africa: perspectives from Nigeria. Indian J Crit Care Med 2009, 13:25-27.

79. Kirigia JM, Barry SP: Health challenges in Africa and the way forward. Int Arch Med 2008, 1:27.

80. Lazarus JV, Wallace SA, Liljestrand J: Improving African health research capacity. Scand J Public Health 2010, 38:670-671.

81. Nwaka S, llunga TB, Da Silva JS, Rial Verde E, Hackley D, De Vre R, Mboya-Okeyo T, Ridley RG: Developing ANDI: a novel approach to health product R\&D in Africa. PLoS Med 2010, 7:e1000293.

82. Wright D, Flis N, Gupta M: The 'Brain Drain' of physicians: historical antecedents to an ethical debate, c. 1960-79. Philos Ethics Humanit Med 2008, 3:24

83. Eastwood JB, Conroy RE, Naicker S, West PA, Tutt RC, Plange-Rhule J: Loss of health professionals from sub-Saharan Africa: the pivotal role of the UK. Lancet 2005, 365:1893-1900.

84. Agwu K, Llewelyn M: Compensation for the brain drain from developing countries. Lancet 2009, 373:1665-1666.

85. Ioannidis JP: Global estimates of high-level brain drain and deficit. FASEB J 2004, 18:936-939.

86. Daar AS, Berndtson K, Persad DL, Singer PA: How can developing countries harness biotechnology to improve health? BMC Public Health 2007, 7:346.

87. Motari M, Quach U, Thorsteinsdottir H, Martin DK, Daar AS, Singer PA: South Africa-blazing a trail for African biotechnology. Nat Biotechnol 2004, 22(Suppl):DC37-DC41 
88. Rotimi CN: Inauguration of the African Society of Human Genetics. Nat Genet 2004, 36:544.

89. Wonkam A, Kenfack MA, Muna WFT, Ouwe-Missi-Oukem-Boyer O: Ethics of human genetic studies in sub-Saharan Africa: the case of Cameroon through a bibliometric analysis. Dev World Bioeth 2011, 11:120-127.

90. Ana JN: Africa's medical brain drain. BMJ 2005, 331:780.

doi:10.1186/1744-8603-9-50

Cite this article as: Peprah and Wonkam: Biomedical research, a tool to address the health issues that affect African populations. Globalization and Health 2013 9:50.

\section{Submit your next manuscript to BioMed Central and take full advantage of:}

- Convenient online submission

- Thorough peer review

- No space constraints or color figure charges

- Immediate publication on acceptance

- Inclusion in PubMed, CAS, Scopus and Google Scholar

- Research which is freely available for redistribution 